\title{
Tranexamic acid for the prevention and management of orthopedic surgical hemorrhage: current evidence
}

This article was published in the following Dove Press journal: Journal of Blood Medicine

25 August 2015

Number of times this article has been viewed

\author{
Christopher Kim \\ Sam Si-Hyeong Park \\ J Roderick Davey \\ Division of Orthopedic Surgery, \\ Toronto Western Hospital, Toronto, \\ Ontario, Canada
}

\begin{abstract}
Total joint arthroplasty can be associated with major blood loss and require subsequent blood transfusions for postoperative anemia. Measures to effectively and safely decrease blood loss and reduce the need for blood transfusions would help improve patient safety and lower health care costs. A possible pharmacological option to reduce surgical blood loss in total joint arthroplasty is the use of tranexamic acid. Abundant literature has shown that intravenous and/or topical administration of tranexamic acid is effective in reducing blood loss and blood transfusions, with no increased risk of venous thromboembolic events or other complications.
\end{abstract}

Keywords: tranexamic acid, total hip arthroplasty, total knee arthroplasty, antifibrinolytic, blood transfusion, blood loss

\section{Introduction to tranexamic acid}

Major elective orthopedic surgery is often associated with blood loss, requiring the need for blood transfusion. Up to $37 \%$ of patients undergoing primary total hip arthroplasty (THA) and 25\% undergoing primary total knee arthroplasty (TKA) require blood transfusion for postoperative anemia. ${ }^{1}$ It is estimated that the average blood loss during primary THA can be between 1,000 and 2,000 $\mathrm{mL} .{ }^{2}$ Likewise, primary TKA may result in a postoperative loss of up to $2,000 \mathrm{~mL}$ of blood. ${ }^{3}$

A possible pharmacological option to prevent surgical bleeding in elective orthopedic surgery is the use of tranexamic acid (TA). TA was originally discovered in 1962 by two independent research groups. ${ }^{4,5}$ The researchers had found that the trans form of 4-(aminomethyl)-cyclohexane-carbonic acid had antifibrinolytic properties. As a synthetic derivative of lysine with a molecular weight of $157 \mathrm{~g} / \mathrm{mol}$, TA exerts its antifibrinolytic effect by a reversible interaction with plasminogen and the active protease, plasmin. ${ }^{6}$

One of the earliest randomized studies examining the efficacy of TA in reducing blood loss following total joint arthroplasty was in 1997 by Hiippala et al. ${ }^{7}$ In their study, 75 patients undergoing primary TKA were randomized to receive either normal saline or intravenous (IV) TA. The TA group showed a significant reduction in blood loss and mean number of transfused units without increase in venous thromboembolic events.

The objective of this review was to comprehensively examine the use of TA as a pharmacologic agent to minimize bleeding following total joint arthroplasty.

Division of Orthopedic Surgery,

Toronto Western Hospital,

399 Bathurst Street, IE-444, Toronto,

Ontario M5T 2S8, Canada

$\mathrm{Tel}+\mathrm{I} 4166035732$

Fax +I 4166033437

Email rod.davey@uhn.ca

\section{Pharmacology of tranexamic acid}

Increased fibrinolytic activity has been shown to be a contributing factor for increased blood loss during total joint arthroplasty. ${ }^{8}$ TA counteracts the fibrinolytic 
process by indirectly blocking the degradation of fibrin. Specifically, TA competitively binds to the lysine-binding sites on plasminogen, but does so in a reversible manner. This subsequently prevents the binding of fibrin to the plasminogen-plasmin tissue activator complex, and thus the degradation of fibrin is blocked. ${ }^{9,10}$

The mechanism of action of TA has been further elucidated through its use in hereditary angioedema. Hereditary angioedema is characterized by recurrent, circumscribed, and nonpitting subepithelial edema, with acute episodes of abdominal pain and risk of asphyxiation. These vasoactive symptoms are caused by a deficiency of C1-esterase inhibitor that results in uncontrolled activation of the complement system and overproduction of fragments. ${ }^{6}$ In the 1970 s, two randomized, double-blinded, crossover trials showed a decrease in the number and severity of attacks of edema in patients treated with TA. ${ }^{11,12}$ The mechanism of action of TA in $\mathrm{C} 1$-esterase inhibitor deficiencies likely depends on its antiplasmin activity, which impairs the release of vasoactive mediators, such as histamine and bradykinin. TA counteracts the continuous activation of the contact and fibrinolytic systems, prevents accumulation of vasopeptides, and reduces the number and severity of attacks of edema in patients. ${ }^{13,14}$

The most common administration route for TA in published studies regarding total joint arthroplasty is the IV route. Andersson et $\mathrm{l}^{15}$ reported that in healthy patients who received an IV dose of $10 \mathrm{mg} / \mathrm{kg}$ of TA, the plasma concentration was highest within 1 hour after injection, with $30 \%$ excreted in the urine after 1 hour, $55 \%$ at 3 hours, and $90 \%$ after 24 hours. ${ }^{15}$ The half-life of IV TA was estimated to be between 80 and 120 minutes. ${ }^{15,16}$ Furthermore, TA rapidly penetrates into the synovial fluid and membranes, reaching the same concentration in the synovial fluid as in plasma at 15 minutes after IV administration. ${ }^{17}$

Topical administration of TA at an intra-articular and/or periarticular soft tissue level is another popular route of administration in total joint arthroplasty. One of the advantages of topical use of TA is the minimal systemic absorption. Wong et $\mathrm{al}^{18}$ reported that plasma levels of topical TA were $70 \%$ lower than an equivalent dose of IV TA. The mean plasma levels after application of low (1.5 g) and high (3.0 g) topical TA doses were 4.5 and $8.5 \mathrm{mg} / \mathrm{L}$, respectively, whereas the plasma level 1 hour after $10 \mathrm{mg} / \mathrm{kg}$ of IV TA was $18 \mathrm{mg} / \mathrm{L}^{18,19}$

After oral and intramuscular administration, TA was rapidly absorbed with maximum plasma concentrations at $2-3$ and 0.5 hours, respectively. The systemic bioavailability of oral TA was approximately $33 \%{ }^{20}$
After administration, TA tissue distribution was highest in the liver, kidneys, and lungs. Since renal excretion is the major route of elimination of TA, the dose in renal impairment has to be adjusted as urinary excretion of TA decreases with increasing plasma creatinine levels. ${ }^{21}$ As a result, McIntyre and Owen ${ }^{22}$ recommend the following dose adjustments: glomerular filtration rate (GFR) $>50 \mathrm{~mL} / \mathrm{min} 50 \%$ of dose, GFR $10-50 \mathrm{~mL} / \mathrm{min} 25 \%$ of dose, GFR $<10 \mathrm{~mL} / \mathrm{min} 10 \%$ of dose, and for patients on continuous renal replacement therapy $25 \%$ of the dose. ${ }^{22}$ However, the dose in hepatic impairment does not need adjustment, as the liver metabolizes only a small amount of administered TA. ${ }^{21}$

\section{Tranexamic acid interactions}

TA exerts an anti-inflammatory effect through the blockade of fibrinolysis and attenuating triggers that may activate the complement system, cytokines, immune cellular responses, and fibrinolytic response. ${ }^{23}$ In a randomized, double-blinded, dose-dependent, Phase IV clinical trial, Jiménez et $\mathrm{al}^{24}$ evaluated the effect of IV TA on the inflammatory response in patients undergoing elective cardiopulmonary bypass (CPB). A total of 80 patients in the single-dose group received $40 \mathrm{mg} / \mathrm{kg}$ of IV TA before CPB and placebo after CPB, and 80 patients in the double-dose group received $40 \mathrm{mg} / \mathrm{kg}$ of IV TA before and after CPB. This study found that prolonged inhibition of fibrinolysis by a double dose of TA reduced bleeding, CPB-mediated inflammatory response, and fibrinolysis. The double-dose TA group showed decreased levels of interleukin- 6 and D-dimer levels. ${ }^{24}$

\section{Safety of tranexamic acid}

TA is contraindicated in patients with hypersensitivity and allergy to TA, history of venous or arterial thrombosis, intrinsic risk for thrombosis or thromboembolism, acute renal failure, subarachnoid hemorrhage, and history of seizures. ${ }^{25}$

Due to the potential risk of increased thrombosis using TA, many studies have excluded patients with a history of thromboembolic events. However, this increased risk has not been reported in randomized clinical trials using TA. For example, in a randomized, placebo-controlled trial, the Clinical Randomization of Antifibrinolytics in Significant Haemorrhage (CRASH-2) trial collaborators evaluated the effects of IVTA in trauma patients with risk of life-threatening bleeding. A total of 20,211 trauma patients were randomly assigned within 8 hours of injury to either TA (loading dose of $1 \mathrm{~g}$ of IV TA, then $1 \mathrm{~g}$ of IV TA over 8 hours) or placebo. The trial did not exclude patients at risk of thrombosis. 
The TA group showed significant reduction in the incidence of fatal and nonfatal thrombotic events, and arterial thrombosis, and there were no increased venous thromboembolic events in the patients receiving IV TA. ${ }^{26}$

In a retrospective cohort study using the US populationbased data of 872,416 THA and TKA procedures, Poeran et $\mathrm{al}^{27}$ determined the effectiveness and safety of different doses of IV TA. TA was effective in reducing the need for transfusions and was not associated with an increased risk for perioperative complications, including venous thromboembolic events and acute renal failure. ${ }^{27}$

\section{Tranexamic acid in total joint arthroplasty}

\section{Intravenous tranexamic acid in total hip arthroplasty and total knee arthroplasty}

Multiple studies have shown that IV TA administration is effective and safe at the evaluated dosages in total joint arthroplasty.

In a prospective, randomized, double-blinded study, Ekback et $\mathrm{al}^{28}$ evaluated the effect of IV TA in patients undergoing primary THA. A total of 20 patients in the control group received normal saline, and 20 patients received two bolus doses of $10 \mathrm{mg} / \mathrm{kg}$ of IV TA (first dose at the start of the THA and the second 3 hours later). A $1 \mathrm{mg} / \mathrm{kg} / \mathrm{h}$ continuous infusion of TA was also started once the first bolus dose was administered. This study found a significant reduction in bleeding both intraoperatively and postoperatively in the TA group. ${ }^{28}$ In another prospective, randomized, double-blinded study, Johansson et $\mathrm{al}^{29}$ investigated the effect of a single bolus of $15 \mathrm{mg} / \mathrm{kg}$ IV TA given at the start of the primary THA. A total of 53 patients received normal saline in the control group and 47 patients received IV TA. The TA group showed significant reduction in both blood loss and the need for postoperative transfusion compared to the control group. There were no increased venous thromboembolic events seen in the cohort of patients receiving IV TA. ${ }^{29}$

In a prospective, randomized, double-blinded trial, Good et $\mathrm{al}^{30}$ assessed the effect of IV TA on blood loss in unilateral, cemented, primary TKA. A total of 24 patients received normal saline, and 27 patients received $10 \mathrm{mg} / \mathrm{kg}$ of IV TA just before tourniquet release and 3 hours later. TA decreased total blood loss by $30 \%$ and reduced transfusions. There were no differences in the complication rates between both groups. ${ }^{30}$ The meta-analysis by Cid and Lozano ${ }^{31}$ included nine randomized controlled trials to examine the use of IVTA administered prior to tourniquet deflation in TKA on postoperative blood loss and transfusion rates. The use of TA significantly reduced the transfusion rate. Unfortunately, this meta-analysis did not specifically examine the risk of venous thromboembolic complications. ${ }^{31}$ In a prospective, randomized, double-blinded study, Alvarez et $\mathrm{al}^{32}$ assessed the effectiveness of IV TA in patients undergoing primary TKA. Forty-nine patients in the control group received normal saline and 46 patients received $10 \mathrm{mg} / \mathrm{kg}$ of IV TA prior to tourniquet release, supplemented by a $1 \mathrm{mg} / \mathrm{kg} / \mathrm{h}$ infusion for 6 hours postoperatively. The TAadministered group showed significant reduction in blood loss and transfusion requirements. There were no significant differences in venous thromboembolic events in the TA group compared with the control group. ${ }^{32}$

\section{Topical tranexamic acid in total hip arthroplasty and total knee arthroplasty}

The efficacy and safety of topical or intra-articular administration of TA have also been extensively assessed in total joint arthroplasty.

In a prospective, randomized, double-blinded study, Alshryda et $\mathrm{l}^{33}$ compared topical TA to normal saline administration in 161 patients undergoing unilateral primary THA. A total of 81 patients received normal saline, and 80 patients received $1 \mathrm{~g}$ of topical TA. The TA group had a higher postoperative hemoglobin level and a significant decrease in the transfusion rate from $32.1 \%$ to $12.5 \%$ in the group receiving $1 \mathrm{~g}$ of topical TA. The incidence of deep vein thrombosis was identical $(n=2)$ for the control and TA groups. ${ }^{33}$ In a recent retrospective study, Chang et $\mathrm{al}^{34}$ evaluated the application of topical TA in primary THA. A total of 154 patients were given $0.5 \mathrm{~g}$ of topical TA at arthrotomy closure compared to 234 patients who were given a topical cocktail solution of analgesic and antibiotic agents. The TA group had higher postoperative hemoglobin levels and a $50 \%$ decrease in transfusion rates, without any concomitant increase in venous thromboembolic events. ${ }^{34}$

In a prospective, randomized, double-blinded trial, Wong et $\mathrm{al}^{18}$ compared low (1.5 g) and high $(3.0 \mathrm{~g})$ doses of topical TA to an equivalent volume of normal saline in 99 patients undergoing unilateral, cemented, primary TKA. In this study, 35 patients received normal saline, 31 patients received $1.5 \mathrm{~g}$ of topical TA, and 33 patients received $3.0 \mathrm{~g}$ of topical TA. Topical TA was applied to the open joint surfaces, after all components were cemented into place, and left for 5 minutes. Both low and high doses of topical TA resulted in a significant reduction in blood loss and transfusion requirements, with minimal systemic absorption and no increase in venous thromboembolic events. ${ }^{18}$ In another 
prospective, randomized, double-blinded study, Alshryda et $\mathrm{a}^{35}$ compared topical TA to normal saline administration in 157 patients undergoing unilateral, cemented, primary TKA. A total of 78 patients received normal saline and 79 patients received $1 \mathrm{~g}$ of topical TA. The TA group had a higher postoperative hemoglobin level and a significant decrease in the transfusion rate, with an absolute risk reduction of $15.4 \%$ in the TA group. There were no differences in the incidence of deep vein thrombosis for the control and TA groups. ${ }^{35}$

Gilbody et $\mathrm{al}^{36}$ retrospectively assessed the effectiveness and safety of topical TA in patients undergoing primary THA and TKA. A total of 86 THA patients and 69 TKA patients were given $3.0 \mathrm{~g}$ of topical TA in the wound and compared with 88 THA patients and 61 TKA patients who did not receive topical TA. Both THA and TKA patients who received topical TA had significant reductions in hemoglobin loss, blood loss, and a significant decrease in transfusion rates (from 19.3\% to $2.3 \%$ in THA patients and $13.1 \%$ to $0 \%$ in TKA patients) without any increase in venous thromboembolic events. ${ }^{36}$ In a recent systematic review and meta-analysis on topical TA in THA and TKA, Alshryda et $\mathrm{al}^{37}$ included 14 randomized controlled trials to evaluate the effect of topical TA on blood loss and rates of transfusions in THA and TKA. The use of topical TA significantly reduced the rate of blood transfusions in both THA and TKA, and the rate of venous thromboembolic events were similar to those found with a control group. ${ }^{37}$

\section{Comparison of IV versus topical tranexamic acid in total joint arthroplasty}

Numerous studies regarding the use of IV and topical TA in total joint arthroplasty have confirmed the efficacy and safety of TA compared with controls.

In a recent randomized, double-blinded, noninferiority trial, Gomez-Barrena et $\mathrm{al}^{38}$ evaluated the efficacy and safety of topical TA compared with IV TA in cemented, primary TKA. A total of 39 patients received $3 \mathrm{~g}$ of topical TA compared with 39 patients who received two IV TA doses of 15 $\mathrm{mg} / \mathrm{kg}$ (one dose before tourniquet release and another dose 3 hours after surgery). The transfusion rate was $0 \%$ in both groups, and no significant differences were observed in blood loss or venous thromboembolic events. ${ }^{38}$ In a meta-analysis on IV and topical TA in THA and TKA, Gandhi et $\mathrm{al}^{39}$ included 33 studies for analysis, 19 for TKA, and 14 for THA. For both THA and TKA, there was a definite benefit for the use IV and

Table I Summary of included studies investigating the use of tranexamic acid in total hip arthroplasty and total knee arthroplasty

\begin{tabular}{|c|c|c|c|c|c|c|}
\hline \multirow[t]{2}{*}{ Study } & \multirow[t]{2}{*}{ Study design } & \multirow[t]{2}{*}{$\begin{array}{l}\text { DVT } \\
\text { prophylaxis }\end{array}$} & \multirow[t]{2}{*}{$\begin{array}{l}\text { Transfusion } \\
\text { criteria }\end{array}$} & \multirow[t]{2}{*}{ Intervention } & \multicolumn{2}{|c|}{$\begin{array}{l}\text { Number o } \\
\text { cases }\end{array}$} \\
\hline & & & & & $\bar{C}$ & TA \\
\hline Ekback et $\mathrm{al}^{28}$ & $\begin{array}{l}\text { THA, } \\
\text { RCT }\end{array}$ & Dalteparin & $\begin{array}{l}\text { All patients had preoperative } \\
\text { autologous blood donation }+ \\
\text { intraoperative autotransfusion }\end{array}$ & $\begin{array}{l}10 \mathrm{mg} / \mathrm{kg} \mathrm{IV} \mathrm{TA} \mathrm{bolus} \mathrm{(start} \mathrm{of} \\
\text { procedure }+3 \text { hours later) } \\
+\mathrm{I} \mathrm{mg} / \mathrm{kg} / \mathrm{h} \text { infusion for } 10 \text { hours } \\
\text { after the first bolus }\end{array}$ & 20 & 20 \\
\hline Johansson et $\mathrm{al}^{29}$ & $\begin{array}{l}\text { THA, } \\
\text { RCT }\end{array}$ & Fragmin & $\mathrm{Hb}<90 \mathrm{~g} / \mathrm{L}$ & Single bolus I 5 mg/kg IV TA & 53 & 47 \\
\hline Good et $\mathrm{a}^{30}$ & $\begin{array}{l}\text { TKA, } \\
\text { RCT }\end{array}$ & Fragmin & $\mathrm{Hb}<90 \mathrm{~g} / \mathrm{L}$ & $\begin{array}{l}10 \mathrm{mg} / \mathrm{kg} \text { IV TA prior to } \\
\text { toumiquet release }+3 \text { hours later }\end{array}$ & 24 & 27 \\
\hline Alvarez et $\mathrm{al}^{32}$ & $\begin{array}{l}\text { TKA, } \\
\text { RCT }\end{array}$ & Bemiparin & $\begin{array}{l}\mathrm{Hb}<80 \mathrm{~g} / \mathrm{L} \text { or patients presented } \\
\text { signs, symptoms, or both of } \\
\text { hypoxia such as tachycardia, } \\
\text { dyspnea, or syncope }\end{array}$ & $\begin{array}{l}10 \mathrm{mg} / \mathrm{kg} \mathrm{IV} \mathrm{TA} 30 \text { minutes } \\
\text { before toumiquet release and } \\
\text { then I } \mathrm{mg} / \mathrm{kg} / \mathrm{h} \text { infusion for } \\
6 \text { hours }\end{array}$ & 49 & 46 \\
\hline Alshryda et $\mathrm{al}^{33}$ & $\begin{array}{l}\text { THA, } \\
\text { RCT }\end{array}$ & Enoxaparin & $\begin{array}{l}\mathrm{Hb}<70 \mathrm{~g} / \mathrm{L} \text { or } \mathrm{Hb}<80 \mathrm{~g} / \mathrm{L} \\
\text { in symptomatic patients }\end{array}$ & I g topical TA & 81 & 80 \\
\hline Chang et $\mathrm{al}^{34}$ & $\begin{array}{l}\text { THA, } \\
\text { retrospective }\end{array}$ & None & $\mathrm{Hb}<100 \mathrm{~g} / \mathrm{L}$ & $0.5 \mathrm{~g}$ topical TA & 234 & 154 \\
\hline Wong et $\mathrm{al}^{18}$ & $\begin{array}{l}\text { TKA, } \\
\text { RCT }\end{array}$ & Enoxaparin & $\begin{array}{l}\mathrm{Hb}<80 \mathrm{~g} / \mathrm{L} \text { or } \mathrm{Hb}<100 \mathrm{~g} / \mathrm{L} \text {, if } \\
\text { symptoms developed }\end{array}$ & $\begin{array}{l}1.5 \text { or } 3 \mathrm{~g} \text { topical TA applied } \\
\text { to joint for } 5 \text { minutes at end } \\
\text { of surgery }\end{array}$ & 35 & $\begin{array}{l}31 \\
33 *\end{array}$ \\
\hline Alshryda et al ${ }^{35}$ & $\begin{array}{l}\text { TKA, } \\
\text { RCT }\end{array}$ & Enoxaparin & $\begin{array}{l}\mathrm{Hb}<70 \mathrm{~g} / \mathrm{L} \text { or } \mathrm{Hb}<80 \mathrm{~g} / \mathrm{L} \text { in } \\
\text { symptomatic patients }\end{array}$ & I g topical TA & 78 & 79 \\
\hline Gilbody et $\mathrm{al}^{36}$ & $\begin{array}{l}\text { THA, } \\
\text { TKA, } \\
\text { retrospective }\end{array}$ & Enoxaparin & $\begin{array}{l}\mathrm{Hb}<80 \mathrm{~g} / \mathrm{L} \text { or } \mathrm{Hb}<100 \mathrm{~g} / \mathrm{L} \text {, if } \\
\text { symptoms developed }\end{array}$ & $3 \mathrm{~g}$ topical TA & 88 & $\begin{array}{l}86 \\
69\end{array}$ \\
\hline
\end{tabular}

Note: *indicates the 31 patients who received $1.5 \mathrm{~g}$ of TA and 33 patients who received $3.0 \mathrm{~g}$ of TA.

Abbreviations: THA, total hip arthroplasty; TKA, total knee arthroplasty; RCT, randomized controlled trial; DVT, deep venous thrombosis; Hb, hemoglobin; IV, intravenous; TA, tranexamic acid; C, control. 
topical TA in reduction of blood loss and transfusion rates. There were no increased risks of complications in either the THA or TKA groups after TA administration. ${ }^{39}$

\section{Conclusion}

Numerous studies conducted with IV and/or topical TA in total joint arthroplasty have shown TA to reduce blood loss and transfusion requirements, with no apparent increase in venous thromboembolism events (Table 1). Indirect comparison of placebo-controlled trials of IV and topical TA indicate that topical TA application is superior to the IV administration. ${ }^{37}$ Topical TA can be a viable alternative in patients with contraindications to IV TA.

TA should be considered for routine use in primary THA and TKA to decrease blood loss. Approving and extending the indications for the use of TA in total joint arthroplasty would be a useful measure to reduce costs and blood transfusions.

\section{Disclosure}

J Roderick Davey has received support from Biomet and Smith \& Nephew, and has previously consulted for Biomet. None are relevant to this review. The authors report no other conflicts of interest in this work.

\section{References}

1. Blumberg N, Kirkley SA, Heal JM. A cost analysis of autologous and allogeneic transfusion in hip-replacement surgery. Am J Surg. 1996;171(3):324-330.

2. Toy PT, Kaplan EB, McVay PA, Lee SJ, Strauss RG, Stehling LC. Blood loss and replacement in total hip arthroplasty: a multicenter study. The preoperative autologous blood donation study group. Transfusion. 1992;32(1):63-67.

3. Kalairajah Y, Simpson D, Cossey AJ, Verrall GM, Spriggins AJ. Blood loss after total knee replacement: effects of computer-assisted surgery. J Bone Joint Surg (Br). 2005;87:1480-1482.

4. Okamoto S, Sato S, Takada Y, Okamoto U. An active stereo-isomer (trans-form) of AMCHA and its antifibrinolytic (antiplasminic) action in vitro and in vivo. Keio J Med. 1964;13:177-185.

5. Melander B, Gliniecki G, Granstrand B, Hanshoff G. Biochemistry and toxicology of amikapron; the antifibrinolytically active isomer of AMCHA. (A comparative study with epsilon-aminocaproic acid). Acta Pharmacol Toxicol (Copenh). 1965;22:340-352.

6. Dunn CJ, Goa KL. Tranexamic acid. A review of its use in surgery and other indications. Drugs. 1999;57:1005-1032.

7. Hiippala ST, Strid LJ, Wennerstrand MI, et al. Tranexamic acid radically decreases blood loss and transfusions associated with total knee arthroplasty. Anesth Analg. 1997;84(4):839-844.

8. Petäjä J, Myllynen P, Myllylä G, Vahtera E. Fibrinolysis after application of a pneumatic tourniquet. Acta Chir Scan. 1987;153:647-651.

9. Samama CM. A direct antifibrinolytic agent in major orthopaedic surgery. Orthopaedics. 2004;27(6 Supp1):S675-S680.

10. Hardy JF, Desroches J. Natural and synthetic antifibrinolytics in cardiac surgery. Can J Anaesth. 1992;39:353-365.

11. Blohmé G. Treatment of hereditary angioneurotic oedema with tranexamic acid: a random double-blind cross-over study. Acta Med Scand. 1972;192:293-298.
12. Sheffer AL, Austen KF, Rosen FS. Tranexamic acid therapy in hereditary angioneurotic edema. N Engl J Med. 1972;287:452-454.

13. Cugno M, Cicardi M, Agostoni A. Activation of the contact system and fibrinolysis in autoimmune acquired angioedema: a rationale for prophylactic use of tranexamic acid. J Allergy Clin Immunol. 1994;93(5):870-876.

14. Du-Thanh A, Raison-Peyron N, Drouet C, Guillot B. Efficacy of tranexamic acid in sporadic idiopathic bradykinin angioedema. Allergy. 2010;65(6):793-795.

15. Andersson L, Nilsson IM, Nilehn JE, Hedner U, Granstrand B, Melander B. Experimental and clinical studies on AMCA, the antifibrinolytically active isomer of p-aminomethyl cyclohexane carboxylic acid. Scand J Haematol. 1965;2:230-247.

16. Eriksson O, Kjellman H, Pilbrant A, Schannong M. Pharmacokinetics of tranexamic acid after intravenous administration to normal volunteers. Eur J Clin Pharmacol. 1974;7:375-380.

17. Ahlberg A, Eriksson O, Kjellman H. Diffusion of tranexamic acid to the joint. Acta Orthop Scand. 1976;47:486-488.

18. Wong J, Abrishami A, El Beheiry H, et al. Topical application of tranexamic acid reduces postoperative blood loss in total knee arthroplasty: a randomized, controlled trial. J Bone Joint Surg (Am). 2010;92:2503-2513

19. Nilsson IM. Clinical pharmacology of aminocaproic and tranexamic acids. J Clin Pathol Suppl (R Coll Pathol). 1980;14:41-47.

20. Pilbrant A, Schannong M, Vessman J. Pharmacokinetics and bioavailability of tranexamic acid. Eur J Clin Pharmacol. 1981;20(1):65-72.

21. Fiechtner BK, Nuttall GA, Johnson ME, et al. Plasma tranexamic acid concentrations during cardiopulmonary bypass. Anesth Analg. 2001;92(5):1131-1136.

22. McIntyre CW, Owen PJ. Prescribing drugs in kidney disease. In: Brenner BM, editor. Brenner and Rector's The Kidney. Philadelphia, PA: Saunders; 2008:1930-1953.

23. Laffey JG, Boylan JF, Cheng DC. The systemic inflammatory response to cardiac surgery: implications for the anesthesiologist. Anesthesiology. 2002;97:215-252.

24. Jiménez JJ, Iribarren JL, Brouard M, et al. Safety and effectiveness of two treatment regimes with tranexamic acid to minimize inflammatory response in elective cardiopulmonary bypass patients: a randomized double-blind, dose-dependent, phase IV clinical trial. J Cardiothorac Surg. 2011;6:138-148.

25. Tengborn L, Blombäck M, Berntorp E. Tranexamic acid-an old drug still going strong and making a revival. Thromb Res. 2015;135(2):231-242.

26. CRASH-2 trial collaborators. Effects of tranexamic acid on death, vascular occlusive events, and blood transfusion in trauma patients with significant haemorrhage (CRASH-2): a randomised, placebo-controlled trial. Lancet. 2010;376:23-32.

27. Poeran J, Rasul R, Suzuki S, et al. Tranexamic acid use and postoperative outcomes in patients undergoing total hip or knee arthroplasty in the United States: retrospective analysis of effectiveness and safety. BMJ. 2014;349:4829-4839.

28. Ekback G, Axelsson K, Ryttberg L, et al. Tranexamic acid reduces blood loss in total hip replacement surgery. Anesth Analg. 2000;91: 1124-1130.

29. Johansson T, Pettersson LG, Lisander B. Tranexamic acid in total hip arthroplasty saves blood and money: a randomized, double-blind study in 100 patients. Acta Orthop. 2005;76:314-319.

30. Good L, Peterson E, Lisander B. Tranexamic acid decreases external blood loss but not hidden blood loss in total knee replacement. $\mathrm{Br} J$ Anaesth. 2003;90:596-599.

31. Cid J, Lozano M. Tranexamic acid reduces allogeneic red cell transfusions in patients undergoing total knee arthroplasty: results of a meta-analysis of randomized controlled trials. Transfusion. 2005;45: 1302-1307.

32. Alvarez JC, Santiveri FX, Ramos I, Vela E, Puig L, Escolano F. Tranexamic acid reduces blood transfusion in total knee arthroplasty even when a blood conservation program is applied. Transfusion. 2008;48: 519-525. 
33. Alshryda S, Mason J, Sarda P, et al. Topical (intra-articular) tranexamic acid reduces blood loss and transfusion rates following total hip replacement: a randomized controlled trial (TRANX-H). J Bone Joint Surg Am. 2013;95(21):1969-1974.

34. Chang C-H, Chang Y, Chen D, Ueng SN, Lee M. Topical tranexamic acid reduces blood loss and transfusion rates associated with primary total hip arthroplasty. Clin Orthop Relat Res. 2014;472(5):1552-1557.

35. Alshryda S, Mason J, Vaghela M, et al. Topical (intra-articular) tranexamic acid reduces blood loss and transfusion rates following total knee replacement: a randomized controlled trial (TRANX-K). J Bone Joint Surg Am. 2013;95(21):1961-1968.

36. Gilbody J, Dhotar HS, Perruccio AV, Davey JR. Topical tranexamic acid reduces transfusion rates in total hip and knee arthroplasty. J Arthroplasty. 2014;29(4):681-684.
37. Alshryda S, Sukeik M, Sarda P, Blenkinsopp J, Haddad FS, Mason JM. A systematic review and meta-analysis of the topical administration of tranexamic acid in total hip and knee replacement. Bone Joint $J$. 2014;96(8):1005-1015.

38. Gomez-Barrena E, Ortega-Andreu M, Padilla-Eguiluz NG, PérezChrzanowska H, Figueredo-Zalve R. Topical intra-articular compared with intravenous tranexamic acid to reduce blood loss in primary total knee replacement: a double-blind, randomized, controlled, noninferiority clinical trial. J Bone Joint Surg Am. 2014;96(23): 1937-1944.

39. Gandhi R, Evans HM, Mahomed SR, Mahomed NN. Tranexamic acid and the reduction of blood loss in total knee and hip arthroplasty: a meta-analysis. BMC Res Notes. 2013;6:184.

\section{Publish your work in this journal}

The Journal of Blood Medicine is an international, peer-reviewed, open access, online journal publishing laboratory, experimental and clinical aspects of all topics pertaining to blood based medicine including but not limited to: Transfusion Medicine; Blood collection, Donor issues, Transmittable diseases, and Blood banking logistics; Immunohematology; Artificial and alternative

\section{Dovepress}

blood based therapeutics; Hematology; Biotechnology/nanotechnology of blood related medicine; Legal aspects of blood medicine; Historical perspectives. The manuscript management system is completely online and includes a very quick and fair peer-review system. Visit http://www.dovepress.com/ testimonials.php to read real quotes from published authors.

Submit your manuscript here: http://www.dovepress.com/Journal-of-blood-medicine-journal 